\title{
Expression of resistance to the pod borer Helicoverpa armigera (Lepidoptera: Noctuidae), in relation to high-performance liquid chromatography fingerprints of leaf exudates of chickpea
}

\author{
V.L. Narayanamma ${ }^{1,2}$, H.C. Sharma ${ }^{1}{ }^{*}$, P.M. Vijay ${ }^{1}$, \\ C.L.L. Gowda ${ }^{1}$ and M. Sriramulu ${ }^{2}$ \\ ${ }^{1}$ International Crops Research Institute for the Semi-Arid Tropics \\ (ICRISAT), Patancheru 502 324, Andhra Pradesh, India; \\ ${ }^{2}$ ANGR Agricultural University, Rajendranagar, Hyderabad 500 030, \\ Andhra Pradesh, India
}

(Accepted 13 July 2013)

\begin{abstract}
The noctuid moth Helicoverpa armigera (Hubner) is the most damaging pest of chickpea worldwide. Plant resistance is an important component for the management of this pest. To develop cultivars with resistance to insects, it is important to understand the role of different components associated with resistance to insects. Therefore, we characterized a diverse array of chickpea genotypes for organic acid profiles in the leaf exudates that are associated with resistance to $H$. armigera. Chickpea leaf exudates contained five major organic acids that were identified as malic, oxalic, acetic, citric and fumaric acids. High-performance liquid chromatography (HPLC) profiles of the leaf exudates of nine chickpea genotypes showed that amounts of malic acid were negatively correlated with leaf feeding by $H$. armigera larvae at flowering and maturity, and with pod damage. Oxalic acid showed a negative association with leaf damage in the detached leaf assay. Additionally, the amounts of acetic acid were negatively correlated with larval weights and damage rating at the flowering and maturity stages. Citric acid levels were negatively associated with damage rating at the flowering stage. Implications of using the HPLC profiles of organic acids in the leaf exudates of chickpea to breed for resistance to H. armigera are discussed.
\end{abstract}

Key words: chickpea, pod borer, Helicoverpa armigera, acid exudates, mechanisms of resistance

\section{Introduction}

Chickpea is the third most important food legume in Asia and North Africa, grown in 10.2 million ha with an annual production of 7.9 million tons and an average productivity of $770 \mathrm{~kg} / \mathrm{ha}(\mathrm{FAO}, 2005)$. It is cultivated in over 45 countries on four continents, i.e. Asia, North and Eastern Africa, Australia and North

*E-mail: h.sharma@cgiar.org
America. More than $80 \%$ of the world's chickpea production area is in India, where it ranks first among the food legumes (10.6 million ha; Chabhra et al., 1990). It is a source of high-quality protein for poor people in many developing countries, including India. Chickpea yields are quite low and have remained almost stagnant for the past two to three decades. Chickpea is damaged by over 50 insect species in different parts of the world, of which the pod borer Helicoverpa armigera (Hubner) 
(Lepidoptera: Noctuidae) is the most injurious (Sharma, 2005; Chen et al., 2011). It causes an estimated loss of US \$328 million in chickpea in the semi-arid tropics. Its control is largely based on insecticides. However, with the development of resistance to insecticides in $H$. armigera populations (Kranthi et al., 2002), there has been a renewed interest in developing alternative methods of pest control, of which plant resistance to $H$. armigera is an important component (Sharma et al., 2005a).

Low to moderate levels of resistance to $H$. armigera have been identified in the chickpea germplasm (Dias et al., 1983; Lateef, 1985; Lateef and Sachan, 1990). Acidic exudates produced by the trichomes on the surface of chickpea plants, of which malic acid and oxalic acid are the principal components, result in oviposition non-preference and antifeedant effects on $H$. armigera (Rembold et al., 1990; Yoshida et al., 1995). The present study focused on the estimation of acid exudates in leaf samples of a diverse array of chickpea genotypes to assess the possibility of using high-performance liquid chromatography (HPLC) fingerprints of organic acids as markers to breed for resistance to $H$. armigera.

\section{Materials and methods}

\section{Evaluation of chickpea genotypes for resistance to $\mathrm{H}$. armigera}

A total of nine chickpea genotypes (eight desi and one kabuli type) were selected (based on earlier evaluation for resistance to $H$. armigera; Lateef and Sachan, 1990; Sharma et al., 2005a) to study the biochemical mechanisms of resistance to the pod borer. Among these, ICC_12475 (ICC_506EB), ICC_12 476, ICC_12 477, ICC_12 478, ICC_12 479 and ICCV_2 (ICC_12968) were moderately resistant (Lateef, 1985; Sharma et al., 2005a), while ICCC_37 (ICC_12 426), ICC_3137 and ICC_4918 were susceptible. The chickpea genotypes were raised on a sterilized mixture of black soil (Vertisols), sand and farmyard manure $(2: 1: 1)$. The soil was transferred into medium-sized pots $(30 \mathrm{~cm}$ diameter and $30 \mathrm{~cm}$ depth). The seeds were sown $5 \mathrm{~cm}$ below the soil surface and watered as required. Ten seeds were sown in each pot and five plants with uniform growth were retained in each pot at 10 days after seedling emergence. The plants were fertilized with diammonium phosphate at $20 \mathrm{~g}$ per pot at 15 days after seedling emergence. There were five pots for each genotype. The plants were raised in a greenhouse, which was cooled by desert coolers $\left(27 \pm 5^{\circ} \mathrm{C}\right.$ and $65-90 \%$ relative humidity). There was no pesticide application. The test material was also evaluated for resistance to $H$. armigera using the detached leaf assay (Sharma et al., 2005b) under laboratory conditions (Narayanamma et al., 2007), and also under natural infestation in the field (Narayanamma et al., 2007, 2013).

\section{Sample collection and estimation of organic acids}

Chickpea plants grown in the greenhouse were used for collection of acid exudates. Glass vials of $15 \mathrm{ml}$ capacity were used for collecting the acid exudates. Ten fully expanded leaflets were collected from each genotype at the flowering stage and placed in the vials. The vials were vortexed for $1 \mathrm{~min}$, and the leaves taken out from the vials and placed on a filter paper. The leaf samples were dried at $55^{\circ} \mathrm{C}$ for 3 days, after which their dry weight was recorded. The water-extracted chemicals were filtered through a $0.45 \mu$ Millipore filter, and $2 \mathrm{ml}$ of the extract were taken into a screw-top vial $(12 \times 32 \mathrm{~mm})$ with an injection needle. The contents were sonicated for $10 \mathrm{~min}$ for dissolving and degassing of the solvents, and then used for HPLC analysis.

The HPLC fingerprinting of the organic acids was carried out by using the Waters 2695 Separations Module HPLC with the Waters 596 photodiode array detector and Atlantis ${ }^{\mathrm{TM}} \mathrm{dC}_{18}$ column $(4.6 \times 250 \mathrm{~mm}, 5 \mu \mathrm{m}$; Waters Corporation, Milford, MA, USA). The mobile phase consisted of $25 \mathrm{~mm}$ $\mathrm{KH}_{2} \mathrm{PO}_{4}(\mathrm{pH} 2.5)$, flow rate $0.8 \mathrm{ml} / \mathrm{min}$ and run time $20 \mathrm{~min}$ per sample. The injected sample volume was $20 \mu \mathrm{l}$. Three samples of each test genotype were run through the HPLC to obtain an estimate of the organic acids present in the water-soluble leaf exudates of different chickpea genotypes. Standard samples of known organic acids (oxalic, malic, citric, fumaric and acetic acids) were used to spike the HPLC peaks to identify the different acids. After the identification of peaks corresponding to the different organic acids, a range of concentrations for each organic acid was run through the HPLC to obtain a normal curve. The amounts of different organic acids present in the leaves of different chickpea genotypes were estimated from the normal curves based on peak areas.

\section{Statistical analysis}

Data were subjected to ANOVA. The significance of differences between the genotypes was tested by the F-test, and the differences between the treatment means were judged by Duncan's multiple range test. The amounts of different organic acids were also correlated with the survival and weights of the $H$. armigera larvae in the detached leaf assay (Narayanamma et al., 2007), and the pod borer at the flowering and podding stages of the crop in the field (Narayanamma et al., 2013) was assessed through Pearson's correlations. The unweighted pair group method with arithmetic averages (UPGMA; Garcia-Vallve et al., 1999) was used to 
assess the diversity (dendrogram) among the chickpea genotypes based on the amounts of the organic acids and the survival and weights of $H$. armigera larvae in the detached leaf assay, and plant damage rating at the flowering and podding stages of the crop in the field.

\section{Results}

\section{HPLC fingerprints of different chickpea genotypes}

Maximum numbers of HPLC peaks were recorded in the leaf exudates of the ICC_12476 and ICC_12477 (13 peaks) genotypes, followed by the ICC_506EB, ICC_12478, ICC_3137 and ICCV_2 (12 peaks) genotypes (Table 1). The lowest number of peaks (six) was recorded in the susceptible check, ICCC_37 (Fig. 1). The peak at retention time (RT) $4.7 \mathrm{~min}$ was observed in all the genotypes, except in ICC_12478 and ICCC_37, while the peak at RT 4.9 min was observed in all the genotypes, except in ICC 4918 and ICCC_37. Peak 8 at RT $9.4 \mathrm{~min}$ was observed in the genotypes ICC_12476 and ICC_12479, while the peak at RT $12.8 \mathrm{~min}$ was observed in all the genotypes, except ICCC_37. The resistant check ICC_506EB had an additional peak at RT $15.5 \mathrm{~min}$. The genotypes ICC_506EB, ICC_12 476, ICC_12478, ICC_12479 and ICCC_37 had three major peaks for oxalic acid, malic acid and acetic acid. The genotypes ICC_12477 and ICCV_2 had an additional peak at RT $3.5 \mathrm{~min}$, while the genotype ICC_3137 had a peak for fumaric acid. The ICC_4918 genotype had major peaks for oxalic acid, malic acid and fumaric acid. There were significant differences in the percentage peak areas for the different organic acids on the surface of chickpea leaves. The percentage peak areas were greater for oxalic acid, malic acid and acetic acid than for the compounds at other peaks. The peak at RT $3.5 \mathrm{~min}$ had significantly greater areas for the genotypes ICC_12477 and ICCV_2 than for the genotype ICC_3137. Peaks for oxalic acid were significantly greater in the genotypes ICC_12477, ICC_12 479, ICC_4918 and ICC_506EB, while those for malic acid were greater in the genotypes ICC_12476, ICC_12478, ICC_12 479 and ICC_506EB than in the susceptible check ICC_3137. Peaks for acetic acid were greater in the genotypes ICC_12 476, ICC_12 478 and ICC_3137, while those of fumaric acid were greater in the genotypes ICC_12 479, ICC_3137, ICC_4918 and ICCV_2.

\section{Organic acids in chickpea genotypes in relation to the expression of resistance to $\mathrm{H}$. armigera}

Significantly higher amounts of oxalic acid were present in the genotype ICC_4918 $(66.33 \mu \mathrm{g} / \mathrm{g})$, followed by the genotypes ICC_12 $477(47.38 \mu \mathrm{g} / \mathrm{g})$ and ICC_506EB $(36.90 \mu \mathrm{g} / \mathrm{g})$ on a wet-weight basis (Table 2). The amounts of malic acid were significantly greater in the genotypes ICC_12476, ICC_12 477, ICC_12478, ICC_12 479, ICCV_2 and ICC_506EB than in the susceptible check, ICCC_37; while the amounts of acetic acid were greater $(>18.9 \mu \mathrm{g} / \mathrm{g})$ in the leaf exudates of the genotypes ICC_12 476, ICC_12 479, ICC_3137, ICC_506EB and ICCV_2 than in the susceptible check, ICCC_37 $(9.71 \mu \mathrm{g} / \mathrm{g})$. The amounts of citric acid were high in the genotypes ICC_506EB, ICC_12477, ICC_4918 and ICCV_2, while the amounts of fumaric acid were high in the genotypes ICC_12479, ICC_3137, ICC_4918 and ICCV_2.

Table 1. Relative amounts (peak area \%) of different compounds in the water-soluble leaf exudates of the nine chickpea genotypes (ICRISAT, Patancheru, India)

\begin{tabular}{|c|c|c|c|c|c|c|c|c|c|c|}
\hline \multirow[b]{2}{*}{ Genotypes } & \multirow[b]{2}{*}{$\begin{array}{l}\text { No. of } \\
\text { peaks }\end{array}$} & \multicolumn{9}{|c|}{ Retention time (min) } \\
\hline & & $\begin{array}{c}3.5 \\
\text { Unknown }\end{array}$ & $\begin{array}{c}3.9 \\
\text { Oxalic } \\
\text { acid }\end{array}$ & $\begin{array}{c}4.7 \\
\text { Unknown }\end{array}$ & $\begin{array}{c}5.9 \\
\text { Malic } \\
\text { acid }\end{array}$ & $\begin{array}{c}6.8 \\
\text { Acetic } \\
\text { acid }\end{array}$ & $\begin{array}{c}9.3 \\
\text { Unknown }\end{array}$ & $\begin{array}{l}12.9 \\
\text { Citric } \\
\text { acid }\end{array}$ & $\begin{array}{c}15.5 \\
\text { Unknown }\end{array}$ & $\begin{array}{c}16.0 \\
\text { Fumaric } \\
\text { acid }\end{array}$ \\
\hline ICC_ 12476 & 13 & $6.6 a$ & $12.7 \mathrm{a}$ & $1.7 \mathrm{c}$ & $25.8 \mathrm{~cd}$ & $16.8 \mathrm{~b}$ & $0.8 \mathrm{~b}$ & $4.6 a$ & $9.3 b$ & $3.8 \mathrm{a}$ \\
\hline ICC_12 477 & 13 & $15.1 \mathrm{~b}$ & $28.4 \mathrm{~b}$ & $1.7 \mathrm{c}$ & $20.9 b c$ & $11.5 \mathrm{ab}$ & $1.1 \mathrm{bc}$ & $4.3 \mathrm{a}$ & $6.1 \mathrm{a}$ & 2.1a \\
\hline ICC_12 478 & 12 & $7.3 a$ & $22.1 \mathrm{a}$ & $1.1 \mathrm{~b}$ & $33.7 \mathrm{e}$ & $16.6 \mathrm{~b}$ & $1.8 \mathrm{~d}$ & $3.4 a$ & - & $6.3 \mathrm{ab}$ \\
\hline ICC_12 479 & 11 & $7.2 \mathrm{a}$ & $17.9 \mathrm{ab}$ & $1.1 \mathrm{~b}$ & $25.4 \mathrm{~cd}$ & $24.5 \mathrm{c}$ & $1.1 \mathrm{bc}$ & $2.7 \mathrm{a}$ & - & $12.1 \mathrm{~b}$ \\
\hline ICC_3137 & 12 & $3.3 a$ & $15.2 \mathrm{a}$ & $0.2 \mathrm{a}$ & $17.9 \mathrm{~b}$ & $27.8 \mathrm{c}$ & $0.7 \mathrm{ab}$ & $3.4 a$ & - & $24.9 c$ \\
\hline ICC_4918 & 10 & 8.1a & $47.1 \mathrm{c}$ & $0.2 \mathrm{a}$ & $10.5 a$ & $9.5 \mathrm{a}$ & $0.7 \mathrm{ab}$ & $6.9 \mathrm{~b}$ & - & $12.5 \mathrm{~b}$ \\
\hline ICCV_2 & 12 & $20.4 \mathrm{~b}$ & $16.4 \mathrm{a}$ & $0.8 \mathrm{ab}$ & $21.1 b c$ & $12.4 \mathrm{ab}$ & $0.3 a$ & $4.2 \mathrm{a}$ & - & $9.7 \mathrm{~b}$ \\
\hline ICC_506EB (R) & 12 & $2.6 a$ & $23.2 \mathrm{ab}$ & $0.6 \mathrm{ab}$ & $24.2 \mathrm{bcd}$ & $12.4 \mathrm{ab}$ & $1.3 \mathrm{c}$ & $9.1 \mathrm{c}$ & $8.7 \mathrm{~b}$ & $5.3 a$ \\
\hline ICCC_37 (S) & 6 & $2.6 a$ & $46.3 c$ & - & $30.4 \mathrm{de}$ & $14.3 \mathrm{ab}$ & - & - & - & $5.9 \mathrm{a}$ \\
\hline Mean & & 8.1 & 25.5 & 0.9 & 23.3 & 16.2 & 1.0 & 4.8 & 8.0 & 9.2 \\
\hline SE & - & $2.0^{*}$ & $4.31^{*}$ & $0.20^{*}$ & $2.28^{*}$ & $2.05^{*}$ & $0.15^{*}$ & $0.71^{*}$ & $0.57^{*}$ & $2.30^{*}$ \\
\hline
\end{tabular}

$R$, resistant check; $S$, susceptible check.

* F-test significant at $P<0.05$. Values followed by the different letters within a column are significantly different by Duncan's multiple range test at $P<0.05$. 

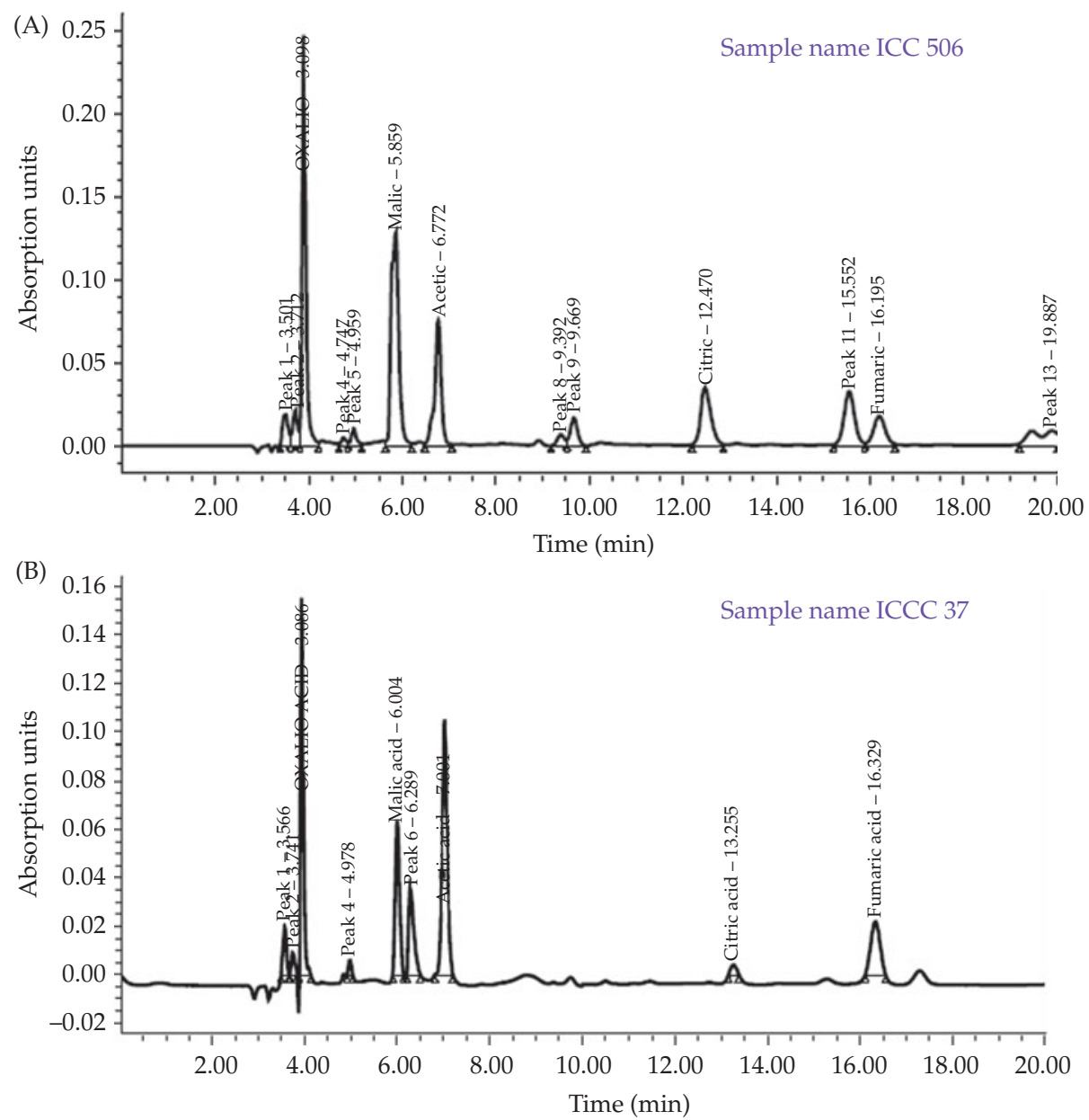

Fig. 1. (colour online) HPLC fingerprints of the water-soluble leaf exudates of (A) ICC_506EB (resistant) and (B) ICCC_37 (susceptible) chickpea genotypes.

Significantly higher amounts of oxalic acid were recorded in the genotypes ICC_4918 $(547.06 \mu \mathrm{g} / \mathrm{g})$ and ICC_12 $477(316.9 \mu \mathrm{g} / \mathrm{g})$ than in the susceptible check, ICCC_37 (152.48 $\mu \mathrm{g} / \mathrm{g})$ on a dry-weight basis (Table 3). Significantly higher amounts of malic and acetic acids were recorded in the genotypes ICC_12476, ICC_12 477, ICC_12 478, ICC_12479, ICCV 2 and ICC_506EB than in the susceptible check, ICCC_37. The amounts of fumaric acid were higher in the genotypes ICC_12479, ICC_3137, ICC_4918 and ICCV_2 than in the other genotypes tested.

\section{Association of organic acids with the expression of resistance to $\mathrm{H}$. armigera}

The peaks at RT 3.52 and $3.90 \mathrm{~min}$ showed a negative and significant association with larval weights $(r=-0.26, P<0.05$ and $-0.28, P<0.01)$, while the peak at RT $3.72 \mathrm{~min}$ showed a negative and significant correlation with larval survival $(r=-0.23, P<0.05)$ (Table 4$)$. The oxalic and acetic acid levels were negatively associated with larval weights $(r=-0.28, P<0.01$ and $-0.27, P<0.05$, respectively). The malic acid level showed a negative and significant correlation with damage caused by $H$. armigera at the flowering $(r=-0.28, P<0.01)$ and maturity $(r=-0.32, P<0.01)$ stages, and pod damage $(r=-0.22, P<0.05)$ under field conditions.

\section{Diversity among the chickpea genotypes based on HPLC fingerprints}

The UPGMA dendrogram based on the peak areas of the compounds at different RTs placed the test genotypes into five groups at $85 \%$ similarity (Fig. 2). Among these, the first group comprised the genotypes ICC_506EB, ICC_12476 and ICC_12479. All these genotypes were resistant to $H$. armigera. The second group consisted of the genotypes ICC_12477 (moderately resistant) and ICCV_2 (moderately susceptible), while another moderately resistant 
Table 2. Amounts $(\mu \mathrm{g} / \mathrm{g})$ of organic acids in the water-soluble leaf exudates of the nine chickpea genotypes (fresh-weight basis) (ICRISAT, Patancheru, India)

\begin{tabular}{lccccc}
\hline Genotypes & Oxalic acid & Malic acid & Acetic acid & Citric acid & Fumaric acid \\
\hline ICC_12476 & $16.15 \mathrm{a}$ & $36.84 \mathrm{~b}$ & $20.47 \mathrm{bcd}$ & $4.94 \mathrm{a}$ & $4.49 \mathrm{a}$ \\
ICC_12477 & $47.38 \mathrm{c}$ & $39.19 \mathrm{~b}$ & $18.42 \mathrm{bc}$ & $6.15 \mathrm{~b}$ & $3.34 \mathrm{a}$ \\
ICC_12478 & $23.87 \mathrm{ab}$ & $41.12 \mathrm{~b}$ & $17.31 \mathrm{abc}$ & $3.21 \mathrm{a}$ & $6.42 \mathrm{a}$ \\
ICC_12479 & $29.74 \mathrm{ab}$ & $47.58 \mathrm{~b}$ & $39.16 \mathrm{e}$ & $3.88 \mathrm{a}$ & $18.77 \mathrm{~b}$ \\
ICC_3137 & $15.04 \mathrm{a}$ & $19.95 \mathrm{a}$ & $26.41 \mathrm{~d}$ & $2.84 \mathrm{a}$ & $23.13 \mathrm{~b}$ \\
ICCV_2 & $31.55 \mathrm{~b}$ & $45.71 \mathrm{~b}$ & $23.09 \mathrm{~cd}$ & $6.85 \mathrm{~b}$ & $17.60 \mathrm{~b}$ \\
ICC_4918 & $66.33 \mathrm{~d}$ & $16.66 \mathrm{a}$ & $12.87 \mathrm{ab}$ & $8.29 \mathrm{~b}$ & $16.58 \mathrm{~b}$ \\
ICC_506EB (R) & $36.90 \mathrm{~b}$ & $43.23 \mathrm{~b}$ & $18.93 \mathrm{~b}$ & $12.24 \mathrm{c}$ & $7.94 \mathrm{a}$ \\
ICCC_37 (S) & $32.58 \mathrm{bc}$ & $24.08 \mathrm{a}$ & $9.71 \mathrm{a}$ & - & $3.92 \mathrm{a}$ \\
Mean & 33.28 & 34.93 & 20.71 & 6.05 & 11.35 \\
SE & $5.32^{*}$ & $3.88^{*}$ & $2.84^{*}$ & $1.04^{*}$ & $2.53^{*}$ \\
\hline
\end{tabular}

$\mathrm{R}$, resistant check; $\mathrm{S}$, susceptible check.

${ }^{*}$ F-test significant at $P<0.05$. Values followed by the different letters within a column are significantly different by Duncan's multiple range test at $P<0.05$.

line, ICC_12478, was placed independently in the third group. The susceptible check ICC_3137 was placed independently in the fourth group, while the genotypes ICCC_37 and ICC_4918 were placed in the fifth group. The HPLC fingerprinting of the water-soluble leaf surface exudates differentiated between the resistant and susceptible genotypes, and these were placed in separate groups. Some of the resistance lines were also placed in separate groups, indicating the presence of diversity in the sources of resistance to $H$. armigera.

\section{Discussion}

Host plant resistance to $H$. armigera in chickpea has largely been attributed to antixenosis for oviposition, antibiosis and recovery resistance (Narayanamma et al., 2007, 2008), and is influenced by the organic acids in the leaf exudates (Rembold, 1981; Bhagwat et al., 1995; Srivastava and Srivastava, 1989; Rembold et al., 1990). However, resistance expressed by the genotypes PDE 2-3, PDE 7-3 and ICC_506 has been attributed to factors other than acidity, while that of PDE 7-2 is due to high acidity. Malic and oxalic acids in the acid exudates are known to play a considerable role in genotypic susceptibility to $H$. armigera. The genotypes ICC_506EB, ICC_12476, ICC_12478, ICC_12479 and ICCC_37 had three major peaks, while the kabuli genotype ICCV_2 had four major peaks. The malic acid content was found to be significantly and negatively associated with damage caused by $H$. armigera at the flowering and maturity stages, while the oxalic acid content was negatively associated with leaf damage rating in the detached leaf assay. Malic acid acts as a

Table 3. Amounts $(\mu \mathrm{g} / \mathrm{g}$ ) of organic acids in the water-soluble leaf exudates of the nine chickpea genotypes (dry-weight basis) (ICRISAT, Patancheru, India)

\begin{tabular}{lccccc}
\hline Genotypes & Oxalic acid & Malic acid & Acetic acid & Citric acid & Fumaric acid \\
\hline ICC_12476 & $159.11 \mathrm{a}$ & $362.79 \mathrm{c}$ & $201.56 \mathrm{c}$ & $48.62 \mathrm{c}$ & $44.25 \mathrm{a}$ \\
ICC_12477 & $316.94 \mathrm{~b}$ & $262.14 \mathrm{~b}$ & $123.19 \mathrm{~b}$ & $41.14 \mathrm{bc}$ & $22.35 \mathrm{a}$ \\
ICC_12478 & $143.14 \mathrm{a}$ & $246.60 \mathrm{~b}$ & $103.83 \mathrm{~b}$ & $19.26 \mathrm{a}$ & $38.48 \mathrm{a}$ \\
ICC_12479 & $175.01 \mathrm{a}$ & $279.98 \mathrm{~b}$ & $230.47 \mathrm{c}$ & $22.81 \mathrm{ab}$ & $110.48 \mathrm{bc}$ \\
ICC_3137 & $102.57 \mathrm{a}$ & $136.01 \mathrm{a}$ & $180.10 \mathrm{c}$ & $19.38 \mathrm{a}$ & $157.73 \mathrm{c}$ \\
ICC_4918 & $547.06 \mathrm{~b}$ & $137.40 \mathrm{a}$ & $106.16 \mathrm{~b}$ & $68.38 \mathrm{~d}$ & $136.73 \mathrm{bc}$ \\
ICCV_2 & $162.77 \mathrm{a}$ & $235.80 \mathrm{~b}$ & $119.13 \mathrm{~b}$ & $35.31 \mathrm{abc}$ & $90.77 \mathrm{~b}$ \\
ICC_506EB (R) & $209.20 \mathrm{a}$ & $245.05 \mathrm{~b}$ & $107.32 \mathrm{~b}$ & $69.38 \mathrm{~d}$ & $45.00 \mathrm{a}$ \\
ICCC_37 (S) & $152.48 \mathrm{a}$ & $112.67 \mathrm{a}$ & $45.46 \mathrm{a}$ & - & $18.32 \mathrm{a}$ \\
Mean & 218.70 & 224.27 & 135.25 & 40.54 & 73.79 \\
SE & $45.6^{*}$ & $27.02^{*}$ & $19.21^{*}$ & $6.8^{*}$ & $17.21^{*}$ \\
\hline
\end{tabular}

$\mathrm{R}$, resistant check; $\mathrm{S}$, susceptible check.

${ }^{*}$ F-test significant at $P<0.05$. Values followed by the different letters within a column are significantly different by Duncan's multiple range test at $P<0.05$. 
Table 4. Association of the peak area with larval survival, larval weights and plant damage in nine chickpea genotypes (ICRISAT, Patancheru, India)

\begin{tabular}{|c|c|c|c|c|c|}
\hline \multirow[b]{2}{*}{$\begin{array}{l}\text { Retention time } \\
(\mathrm{min})\end{array}$} & \multirow[b]{2}{*}{$\begin{array}{l}\text { Water-soluble } \\
\text { organic acids }\end{array}$} & \multirow[b]{2}{*}{$\begin{array}{c}\text { Larval } \\
\text { survival }\end{array}$} & \multirow[b]{2}{*}{ Larval weight } & \multicolumn{2}{|c|}{$\begin{array}{l}\text { Pod borer damage } \\
\text { rating }^{+}\end{array}$} \\
\hline & & & & $\begin{array}{l}\text { Flowering } \\
\text { stage }\end{array}$ & Maturity \\
\hline 3.52 & Unknown & -0.04 & $-0.26^{*}$ & 0.02 & -0.05 \\
\hline 3.72 & Unknown & $0.23^{*}$ & $-0.22^{*}$ & -0.12 & 0.01 \\
\hline 3.90 & Oxalic acid & 0.20 & $-0.28^{* *}$ & -0.19 & -0.12 \\
\hline 4.98 & Unknown & 0.08 & -0.02 & -0.07 & -0.01 \\
\hline 5.92 & Unknown & 0.03 & 0.14 & 0.10 & 0.16 \\
\hline 5.93 & Malic acid & -0.13 & -0.03 & $-0.28^{* *}$ & $-0.32^{* *}$ \\
\hline 6.89 & Acetic acid & 0.07 & $-0.27^{*}$ & -0.09 & 0.06 \\
\hline 6.82 & Unknown & 0.07 & -0.08 & $-0.23^{*}$ & $-0.28^{* *}$ \\
\hline 10.33 & Unknown & $0.42^{* *}$ & $-0.24^{*}$ & -0.08 & -0.02 \\
\hline 12.95 & Citric acid & $-0.25^{*}$ & $-0.23^{*}$ & -0.03 & 0.09 \\
\hline 16.00 & Fumaric acid & 0.00 & 0.11 & -0.16 & -0.07 \\
\hline 16.76 & Unknown & 0.07 & 0.05 & 0.04 & $0.23^{*}$ \\
\hline
\end{tabular}

${ }^{*}$ Correlation coefficients significant at $P<0.05$.

**Correlation coefficients significant at $P<0.01$.

+ Pod borer damage rating $(1,<10 \%$ leaf area and/or pods damaged and $9,>80 \%$ leaf area and/or pods damaged).

deterrent to the $H$. armigera larvae, and the pod borer-resistant lines have higher amounts of malic acid than the susceptible lines (Bhagwat et al., 1995). Oxalic acid has been shown to inhibit the growth of $H$. armigera larvae when incorporated in an artificial diet, while no such effects have been shown by malic acid (Yoshida et al., 1995, 1997). Acetic acid showed a negative association with larval weight gain and $H$. armigera damage rating at the flowering and maturity stages, while citric acid showed a negative and significant association with leaf damage at the flowering stage. Leaves

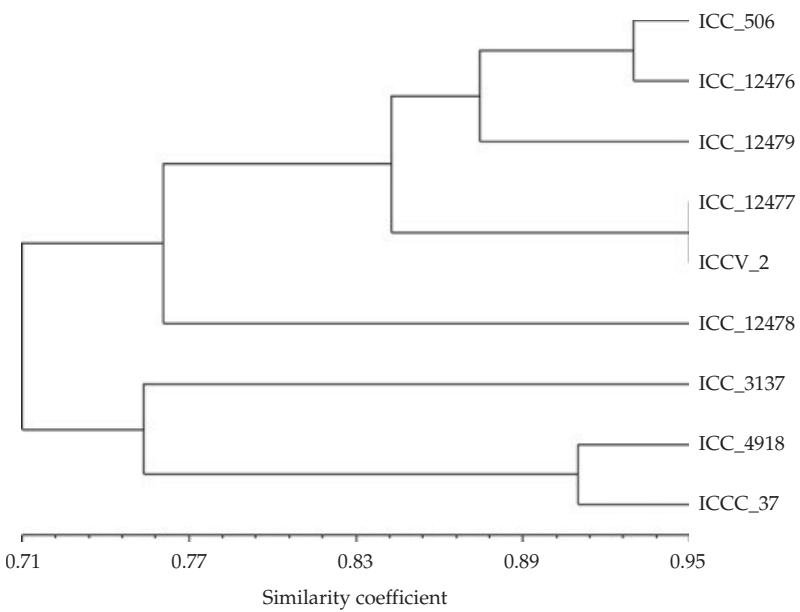

Fig. 2. Dendrogram (based on the UPGMA) depicting the similarity between the nine chickpea genotypes, based on the HPLC fingerprints of the water-soluble leaf exudates. at the flowering and early podding stages would be the most appropriate for chemical analysis, as the differences in organic acid levels between the resistant and susceptible genotypes were most marked at this growth stage. Antifeedant and/or antibiotic properties of organic acids may influence the host selection and feeding behaviour, and thus influence the growth and development of $H$. armigera larvae and determine the extent of damage on a particular genotype (Rembold and Winter, 1982; Rembold et al., 1990). The present study indicated that in addition to oxalic and malic acids, citric acid, acetic acid and fumaric acid also play an important role in genotypic resistance to $H$. armigera. Monitoring the amounts of organic acids through HPLC can be used to select chickpea genotypes for resistance to $H$. armigera. The HPLC fingerprinting placed the resistant and susceptible lines in different groups, while some of the lines showing resistant reactions were placed in different groups, indicating that these lines have different profiles of leaf surface exudates that contribute to resistance/susceptibility to $H$. armigera. The lines showing resistance to $H$. armigera, but placed in different groups, can be used to increase the levels of resistance to this pest.

\section{Acknowledgements}

The authors thank the entomology staff for their help and Dr Rajiv Varshney for reviewing the manuscript. They also thank Mr Suraj P. Sharma for revising the manuscript. 


\section{References}

Bhagwat V. R., Aherkar S. K., Satpute U. S. and Thakare H. S. (1995) Screening of chickpea (Cicer arietinum L.) genotypes for resistance to gram pod borer, Heliothis armigera (Hubner) and its relationship with malic acid in leaf exudates. Journal of Entomological Research 19, 249-253.

Chabhra K. S., Kooner B. S., Sharma A. K. and Saxena A. K. (1990) Sources of resistance in chickpea, role of biochemical components on the incidence of gram pod-borer Helicoverpa (Heliothis) armigera (Hubner). Indian Journal of Entomology 52, 423-430.

Chen W., Sharma H. C. and Muehlbauer F. J. (eds) (2011) Compendium of Chickpea and Lentil Diseases and Pests. American Phytopathological Society, St. Paul, MN. 164 pp. (ISBN 978-0-89054-383-2).

Dias C. A. R., Lal S. S. and Yadava C. P. (1983) Differences in susceptibility of certain chickpea cultivars and local collection to Heliothis armigera (Hubner). Indian Journal of Agricultural Sciences 53, 842-845.

FAO (Food and Agriculture Organization of the United Nations) (2005) FAO Statistical Yearbook 2005-2006 (includes CD-ROM) (multilingual edn). FAO, Rome. 320 pp. (ISBN 978-9250055060).

Garcia-Vallve S., Palau J. and Romeu A. (1999) Horizontal gene transfer in glycosyl hydrolases inferred from codon usage in Escherichia coli and Bacillus subtilis. Molecular Biology and Evolution 9, 1125-1134.

Kranthi K. R., Jadhav D. R., Kranthi S., Wanjari R. R., Ali S. S. and Russell D. A. (2002) Insecticide resistance in five major pests of cotton in India. Crop Protection 21, 449-460.

Lateef S. S. (1985) Gram pod borer (Heliothis armigera) (Hub.) resistance in chickpeas. Agriculture, Ecosystems and Environment 14, 95-102.

Lateef S. S. and Sachan J. N. (1990) Host plant resistance to Helicoverpa armigera (Hub.) in different agro-economical conditions, pp. 181-189. In Chickpea in the Nineties. Proceedings of the Second International Workshop on Chickpea Improvement, 4-8 December 1989, ICRISAT Centre, India. International Crops Research Institute for the Semi-Arid Tropics (ICRISAT), Patancheru and International Centre for Agricultural Research in the Dry Areas (ICARDA), Allepo, Syria. (ISBN 9789290661818).

Narayanamma V. L., Gowda C. L. L., Sriramulu M., Ghaffar M. A. and Sharma H. C. (2013) Nature of gene action and maternal effects for pod borer, Helicoverpa armigera resistance and grain yield in chickpea, Cicer arietinum. American Journal of Plant Sciences 4, 26-37.

Narayanamma L. V., Sharma H. C., Gowda C. L. L. and Sriramulu M. (2007) Mechanisms of resistance to Helicoverpa armigera and introgression of resistance genes into $\mathrm{F}_{1}$ hybrids in chickpea. Arthropod-Plant Interactions 1, 263-270.

Narayanamma L. V., Sharma H. C., Gowda C. L. L. and Sriramulu M. (2008) Incorporation of lyophilized leaves and pods into artificial diet to assess antibiosis component of resistance to pod, Helicoverpa armigera (Lepidoptera: Noctuidae) in chickpea. International Journal of Tropical Insect Science 27, 191-198.

Rembold H. (1981) Malic acid in chickpea exudate - a marker for Heliothis resistance? International Chickpea Newsletter 4, 18-19.

Rembold H., Wallner P., Kohne A., Lateef S. S., Grune M. and Weigner C. (1990) Mechanism of host plant resistance with special emphasis on biochemical factors, pp. 191-194. In Chickpea in the Nineties. Proceedings of the Second International Workshop on Chickpea Improvement, 4-8 December 1989, ICRISAT Centre, India. International Crops Research Institute for the Semi-Arid Tropics (ICRISAT), Patancheru and International Centre for Agricultural Research in the Dry Areas (ICARDA), Allepo, Syria. (ISBN 9789290661818).

Rembold H. and Winter E. (1982) The chemists's role in host plant resistance studies. In Proceedings of the International Workshop on Heliothis Management, 15-20 November 1981. International Crops Research Institute for the Semi Arid Tropics, Patancheru, India.

Sharma H. C. (ed.) (2005) Heliothis/Helicoverpa Management: Emerging Trends and Strategies for Future Research. Oxford \& IBH Publishers, New Delhi. 469 pp.

Sharma H. C., Ahmad R., Ujagir R., Yadav R. P., Singh R. and Ridsdill-Smith T. J. (2005a) Host plant resistance to cotton bollworm/legume pod borer, Helicoverpa armigera, pp. 167-208. In Heliothis/Helicoverpa Management: Emerging Trends and Strategies for Future Research (edited by H. C. Sharma). Oxford \& IBH, New Delhi.

Sharma H. C., Pampapathy G., Dhillon M. K. and Ridsdill-Smith T. J. (2005b) Detached leaf assay to screen for host plant resistance to Helicoverpa armigera. Journal of Economic Entomology 98, 568-576.

Srivastava C. P. and Srivastava R. P. (1989) Screening for resistance to gram pod borer, Heliothis armigera (Hubner) in chickpea (Cicer arietinum L.) genotypes and observations on its mechanism of resistance in India. International Journal of Tropical Insect Science 10, 255-258.

Yoshida M., Cowgill S. E. and Wightman J. A. (1995) Mechanism of resistance to Helicoverpa armigera (Lepidoptera: Noctuidae) in chickpea: role of oxalic acid in leaf exudate as an antibiotic factor. Journal of Economic Entomology 88, 1783-1786.

Yoshida M., Cowgill S. E. and Wightman J. A. (1997) Roles of oxalic and malic acids in chickpea trichome exudate in host-plant resistance to Helicoverpa armigera. Journal of Chemical Ecology 22, 1195-1210. 